\title{
RECEPCIJA HERCEGA STJEPANA VUKČIĆA KOSAČE U UDŽBENIČKOJ LITERATURI I INSTITUCIONALNOJ MEMORIJI U HERCEGOVINI U DRUGOJ POLOVICI 20. STOLJEĆA
}

\author{
Božo GOLUŽA \\ Filozofski fakultet \\ Matice hrvatske b.b. \\ $\mathrm{BiH}$ - 88000 Mostar \\ E-pošta: bozo.goluza@sve-mo.ba \\ Dijana KORAĆ \\ Filozofskifakultet \\ Matice hrvatske b.b. \\ $\mathrm{BiH}$ - 88000 Mostar \\ E-pošta: dijana.korac@sve-mo.ba
}

UDK: 94(073)(097)"19":929.7 Kosača S. V.

Prethodno priopćenje

Primljeno: 17. studenoga 2016.

Prihvaćeno: 5. travnja 2017.

\section{Sažetak}

U radu se nastoji prikazati recepcija hercega Stjepana Vukčića Kosače u Hercegovini u drugoj polovici 20. stoljeća s posebnim naglaskom na razdoblje u kojemu je Bosna i Hercegovina bila jedna od republika bivše Jugoslavije. S obzirom na činjenicu da bi se barem početno znanje o hercegu Stjepanu trebalo steći tijekom osnovnoga i srednjoškolskoga obrazovanja, najprije je dat osvrt na nastavne planove i programe u kojima su, između ostaloga, naznačeni ciljevi (zadatci) nastave povijesti, a zatim se analiziraju tekstovi u udžbenicima povijesti koji su bili u uporabi u bh. školama (osnovnim i gimnazijama), u kojima se u određenim nastavnim jedinicama obrađuje djelovanje hercega Stjepana. Sudeći prema nastavnim planovima i 
programima, kao i sadržaju udžbenika iz druge polovice 20. stoljeća (barem nama dostupnima), mladež u Hercegovini u razmatranom razdoblju nije mogla mnogo saznati i naučiti o ovoj povijesnoj osobi, s čijom je titulom povezano ime prostora u kojemu žive. Na kraju istražuje se hercegova prisutnost u nazivima ulica, trgova i institucija $\mathrm{u}$ hercegovačkim gradovima i općinama. Istraživanje pokazuje da je tek u novije vrijeme evidentan interes nekih pojedinaca i institucija koje žele ovoj povijesnoj osobi dati značenje koje joj pripada. Naime, sve ulice u Hercegovini koje nose njegovo ime, kao i jedna institucija, imenovane su nakon 1990. godine.

Ključne riječi: herceg Stjepan Vukčić Kosača; Hercegovina; recepcija; udžbenici povijesti; ulice.

\section{Uvod}

S ciljem prikazivanja recepcije hercega Stjepana Vukčića Kosače u Hercegovini u drugoj polovici 20. stoljeća, u radu se analiziraju sadržaji u udžbenicima povijesti koji govore o životu i djelovanju ovoga velikaša. Naime, treba imati na umu da za usvajanje predodžbi o nekim povijesnim osobama i događajima možda najveći utjecaj imaju udžbenici povijesti, pa bi se barem početno znanje o hercegu Stjepanu trebalo steći tijekom osnovnoga i srednjoškolskoga obrazovanja. S obzirom da se razmatra razdoblje druge polovice 20. stoljeća, najviše pažnje posvećeno je vremenu u kojemu je Bosna i Hercegovina bila jedna od republika bivše Jugoslavije. Kako su po našemu sudu za ilustraciju nastavnih sadržaja iz srednjovjekovne povijesti, odnosno vezanih uz hercega Stjepana veoma važni nastavni planovi i programi, najprije se donosi kratki osvrt na njih, a posebno na zadatke (ciljeve) nastave povijesti koji su u njima naznačeni. Nakon toga donosi se pregled tekstova u udžbenicima povijesti koji govore o hercegu Stjepanu, iz kojih se može vidjeti koliko je mladež u ovome razdoblju mogla naučiti o povijesnoj osobi s čijom je titulom povezano ime prostora u kojemu žive. No, treba naglasiti da pri tome nije razmatrano (ne)slaganje sadržaja u udžbenicima sa stajalištima suvremene znanosti, a ni s današnjom historiografijom. Vezano uz udžbenike povijesti iz razmatranoga razdoblja, također je važno naglasiti kako na području Hercegovine 90-ih godina 20. stoljeća nije 
bilo službenih udžbenika, pa se u radu donose, ilustracije radi, samo tekstovi dva udžbenika (jedan za osnovnu školu, a drugi za gimnaziju) za koje znamo da su bili rabljeni u nekim školama u Hercegovini. Nakon toga analizira se drugi indikator koji govori o recepciji hercega Stjepana u Hercegovini, a to je imenovanje ulica i institucija koje nose njegovo ime.

\section{Nastavni planovi i programi u službi komunističke ideologije}

U komunističkoj Jugoslaviji poseban naglasak bio je na obrazovanju koje je mladež u toj i takvoj političkoj i društvenoj zajednici trebalo formirati u "svestrano razvijene ličnosti socijalističkog društva". ${ }^{1}$ Prije svega treba imati na umu da su udžbenici pisani u skladu s nastavnim planovima i programima, koje su odobravala posebna povjerenstva, a poseban naglasak bio je na tzv. nacionalnoj skupini predmeta u kojoj je važno mjesto imala nastava povijesti.

Kako su tijekom razmatranoga razdoblja uvođene određene reforme $\mathrm{u}$ školskome sustavu, tako se i povijest prema nastavnom planu i programu učila u različitim razredima s drugačijom tjednom nastavnom satnicom, a od školske 1950./1951. počinje obvezno osmogodišnje obrazovanje u Bosni i Hercegovini. ${ }^{2}$ Valja napomenuti da je u prvim poratnim godinama Bosna i Hercegovina imala brojne poteškoće u organizaciji nastave, a analfabetizam je bio daleko veći nego u nekim drugim republikama, pa je zanimljivo u tom kontekstu spomenuti kako je 1947. godine Ministarstvo za nauku i kulturu Vlade Federativne Narodne Republike Jugoslavije (FNRJ), s ciljem popravljanja postojeće situacije uputilo poziv učiteljima s područja cijele FNRJ za

1 Miljkan Todorović, "Neki problemi nastave istorije u osnovnoj školi", u: Nastava istorije u osnovnoj školi, Savezni zavod za proučavanje školskih i prosvetnih pitanja. Grupa za opšteobrazovne škole, Beograd, 1962., str. 1.

2 O tome vidjeti u: Nastavni plan i program za osnovne škole Narodne Republike Bosne i Hercegovine, Izdanje "Svjetlost" državnog izdavačkog preduzeća Bosne i Hercegovine, Sarajevo, 1948., str. 7; Privremeni nastavni plan i program za niže razrede gimnazija $i$ više razrede osmogodišnjih škola, Svjetlost, Sarajevo, 1954., str. 3; Nastavni plan i program za osnovne škole, Svjetlost, Sarajevo, ${ }^{2} 1960$., str. 13; Nastavni plan i program za osnovnu školu, Republički prosvjetno-pedagoški zavod, Sarajevo, 1975., str. 189-201; Nastavni plan i program zajedničke vaspitno-obrazovne osnove za srednje usmjereno obrazovanje $i$ vaspitanje, Republički prosvjetno-pedagoški zavod, Sarajevo, 1980., str. 157-175; Mitar Papić, Školstvo u Bosni i Hercegovini (1941-1955), "Svjetlost" OOUR Zavod za udžbenike i nastavna sredstva, Sarajevo, 1981., str. 113-114. 
dobrovoljnim radom u $\mathrm{BiH}$, pri čemu se iz Hrvatske i Srbije javilo po 79 učitelja, a iz Crne Gore tri. ${ }^{3}$ Osim toga, treba reći da se od početka ukazivalo na potrebe pisanja adekvatnoga udžbenika povijesti. O planiranju pisanja novih udžbenika povijesti govori dopis A. Matića, povjerenika za prosvjetu ZAVNOBiH-a upućen ministarstvu prosvjete DFJ iz 1945. godine u kojemu stoji: "Osjećamo veliku potrebu za novim udžbenikom istorije kao i priručnikom za nastavnike. Do sada nismo bili u mogućnosti da za izradu takovih knjiga sastavimo komisiju od lica koja bi imala dovoljno stručnog znanja i koja bi znala da pitanje naše istorije postave ideološki i ispravno." ${ }^{\prime 4} \mathrm{U}$ prvim godinama komunističke Jugoslavije kao udžbenik učenicima učiteljskih škola i kao pomoćna literatura učiteljima u osnovnim školama služila je Gitisova Metodika osnovne nastave istorije, ${ }^{5}$ a u NR Hrvatskoj tiskana je knjiga Ante Babića, Historija naroda Jugoslavije. ${ }^{6}$ Naime, Babićevu je knjigu kao priručnik za srednje škole odobrio Komitet za škole i nauku pri vladi FNRJ 1946. godine ali je uskoro naišla na kritike, posebno Milovana Đilasa koji za ovaj udžbenik kaže da je: "nacionalno-nihilistički, on potire i prećutkuje ono što je veliko, herojsko i progresivno u našoj prošlosti, one konkretne ljude i pokrete koji su kretali razvitak naših naroda naprijed, a sve to radi prividnog zadovoljenja nekih apstraktnih pojmova o razvitku društva, odnosno principa istoriskog materijalizma (koje on, uzgred budi rečeno, takođe nepravilno shvata)".?

Sadržaj u udžbenicima povijesti imao je tendenciju prilagođavanja učeničkom uzrastu, a predstavljanje određenoga gradiva ovisilo je i o sposobnosti autora. No, treba imati na umu da su pri svemu tome važni zadatci nastave povijesti koji se donose u nastavnim planovima i programima, pa je prije iznošenja sadržaja vezanih uz hercega

3 Ivan Hofman, "Osnovno i srednje obrazovanje u Jugoslaviji 1945-1952", u: Branka Doknić - Milić F. Petrović - Ivan Hofman (prir.), Kulturna politika Jugoslavije 1945-1952. Zbornik dokumenata, knjiga 1, Beograd, 2009., str. 77.

4 Branka Doknić - Milić F. Petrović - Ivan Hofman (prir.), Kulturna politika Jugoslavije 1945-1952. Zbornik dokumenata, Knjiga 1, Beograd, 2009., str. 246 (dokument br. 93).

5 I. V. Gitis, Metodika osnovne nastave istorije, Prosveta, Beograd, 1946. (ćir.)

6 B. Doknić - M. F. Petrović - I. Hofman (prir.), Kulturna politika Jugoslavije 1945-1952. Zbornik dokumenata, str. 377 (dokument br. 161).

7 Milovan Đilas, "O nacionalnoj istoriji kao vaspitnom predmetu", u: Komunist, III(1)/1949., str. 59-60. 
Stjepana u bh. udžbenicima potrebno osvrnuti se na zadatke nastave povijesti u ovome razdoblju. ${ }^{8}$ Odmah valja kazati da je u nastavnim planovima i programima tijekom navedenoga razdoblja konstantan zadatak "širenje bratstva i jedinstva", odnosno "razvijanje patriotske svijesti kod učenika", te da je naglasak u učenju povijesti bio stavljen na "novije razdoblje". Tako se već u nastavnom planu i programu za osnovne škole u Bosni i Hercegovini, koji je odobren odlukom Ministarstva prosvjete Narodne Republike Bosne i Hercegovine 28. srpnja 1948., među zadatcima nastave povijesti, osim "upoznavanja s najvažnijim događajima", nalazi: "da učvršćuje i dalje razvija bratstvo i jedinstvo i ostale tekovine Narodnooslobodilačke borbe" te "da razvija osjećanje ponosa svojom domovinom, njenom slavnom prošlošću i uspjesima u sadašnjosti, da razvija nepomirljivu mržnju prema neprijateljima otadžbine, prema svima onima koji rade protiv tekovina Narodnooslobodilačke borbe". ${ }^{9}$ Nastavni plan za osnovne škole iz 1960. godine među zadatcima nastave povijesti na prvome mjestu navodi: "da upozna učenike sa najznačajnijim razdobljem prošlosti naših naroda i njihovom borbom za slobodu, a naročito sa novijim periodima naše istorije i Narodnooslobodilačkom borbom te da tako doprinese razvijanju patriotske svijesti u učenika". ${ }^{10}$

Valja napomenuti da su zadatci nastave povijesti bili isti u svim republičkim programima, a jedina je razlika bila u formulaciji i redoslijedu tih zadataka. ${ }^{11}$ Zanimljivo je vidjeti kako se ovih godina gledalo na promjene $\mathrm{u}$ obrazovanju i koje su to probleme u nastavi povijesti detektirali ondašnji školski stručnjaci. Ta tema bila je predmet rada objavljenoga u tadašnjem beogradskom časopisu Nastava istorije $u$ osnovnoj školi. ${ }^{12}$ Raspravljajući o razlikama u programima za nastavu povijesti po pojedinim republikama neki su bili mišljenja da ne

8 Ne ćemo navoditi sve zadatke nastave povijesti nego samo one koji po našem sudu najbolje ilustriraju položaj ovoga predmeta u nastavi, odnosno na kojim je razdobljima bio akcent.

9 Nastavni plan i program za osnovne škole Narodne Republike Bosne i Hercegovine, Izdanje "Svjetlost" državnog izdavačkog preduzeća Bosne i Hercegovine, Sarajevo, 1948., str. 22.

10 Nastavni plan i program za osnovne škole, Svjetlost, Sarajevo, ${ }^{2} 1960$. , str. 159. Sličnu formulaciju nalazimo i u nastavnom planu za osnovne škole iz 1964. godine. Usp. Nastavni plan i program za osnovne škole, Zavod za izdavanje udžbenika, Sarajevo, 1964., str. 191.

11 O tome: M. Todorović, "Neki problemi nastave istorije u osnovnoj školi", str. 3.

12 Isto, str. 1-2. 
postoje objektivna opravdanja za te različitosti, apelirajući da "ako su neki momenti bilo iz opšte ili nacionalne istorije po svojoj obrazovnoj i vaspitnoj vrednosti bitni za realizaciju zadataka nastave istorije u osnovnoj školi, onda oni u svakom slučaju treba da nađu mesto u svim republičkim programima". ${ }^{13}$ Izgleda da je takva bila i nastavna jedinica "Propast feudalnih država Južnih Slovena" pri čemu se obradivala i propast Hercegovine ${ }^{14}$ Iste zadatke s izmijenjenim formulacijama nalazimo i u nastavnom planu i programu za osnovnu školu u SR BiH koji je odobren 1972. a dopunjen 1975. godine. ${ }^{15}$ Valja reći i da je u izvješću za XXXIV. međunarodnu konferenciju u Ženevi 1973. godine iznesen zaključak da su nastavni planovi i programi za gimnazije preopširni i da se planira njihovo sažimanje. ${ }^{16}$

Nakon što je 1981. godine potpisan Dogovor socijalističkih republika i pokrajina o zajedničkim osnovama u sustavu odgoja i obrazovanja, počelo se i s dogovaranjem oko zajedničke programske jezgre koja bi se predavala u svim republikama i pokrajinama, a svaka republika i pokrajina imala bi i svoje specifične sadržaje. Prema ovome dogovoru za nastavni predmet povijesti bilo bi $60 \%$ zajedničke programske jezgre a u nekim razredima i više od toga. Ovu zajedničku programsku jezgru (posebno za osnovnu školu a posebno za usmjereno obrazovanje) odobrila je 1983. godine Međurepubličko-pokrajinska konferencija zavoda za unapređivanje odgoja i obrazovanja. ${ }^{17} \mathrm{U}$ tom

13 Isto, str. 7-8.

14 Nastavni plan i program za gimnaziju, Zavod za izdavanje udžbenika, Sarajevo, 1963., str. 72 .

15 Zadatci nastave povijesti jesu "da razvija kod učenika ljubav i poštovanje prema borbenim i slobodoljubivim tradicijama naših naroda, da u njima izgradi ubjeđenje o neminovnosti postojanja i dalje izgradnje samoupravne socijalističke Jugoslavije na bazi ravnopravnosti svih njenih naroda i narodnosti", te "da doprinese formiranju učenika u svjesne graditelje našeg samoupravnog socijalizma i odlučne borce za zaštitu i odbranu socijalističke Jugoslavije, da ih vaspitava (odgaja) u duhu bratstva i jedinstva naših naroda i narodnosti, jugoslovenskog socijalističkog patriotizma, međunarodne solidarnosti i internacionalizma". Nastavni plan i program za osnovnu školu, Republički prosvjetno-pedagoški zavod, Sarajevo, 1975., str. 189.

16 Razvoj i promene u obrazovanju u SFR Jugoslaviji (1971-1973. g.) Pripremljeno za XXXIV medjunarodnu konferenciju (Ženeva, septembar, 1973), Jugoslovenska komisija za saradnju s UNESKOM i Jugoslovenski zavod za proučavanje školskih i prosvetnih pitanja, Beograd, 1973., str. 39, 47.

17 "Zajednička programska jezgra za nastavu povijesti", u: Pouk zgodovine / Nastava istorije / Nastava povijesti / Nastava po istorija, Zagreb, 1/1984., str. 
tekstu među zadatcima nastave povijesti, između ostaloga, stoji i sljedeće: "da upućuje na povijesne korijene bratstva i jedinstva jugoslavenskih naroda i narodnosti...", ${ }^{18}$ dok u naknadnim objašnjenjima stoji: "Kao nastavni predmet povijest ima posebnu ulogu u odgoju mladih generacija i njihovoj pripremi za uključivanje u našu samoupravnu socijalističku zajednicu."19 Osim toga, valja naglasiti kako se ovdje također navodi da su "novija razdoblja - posebno međuratno razdoblje, drugi svjetski rat, narodnooslobodilačka borba i socijalistička revolucija te socijalistička izgradnja Jugoslavije - dobila važnije mjesto ne samo zbog toga što su bogatija zbivanjima i složenija već i zato što su s gledišta odgojnih zadataka aktualnija". ${ }^{20} \mathrm{Iz}$ ovih navoda jasno se vidi kako se shvaćala nastava povijesti i koje je povijesno razdoblje bilo "najvažnije". Slijedeći ove smjernice, nije ni čudno što je čitava povijest zapravo gledana kroz prizmu revolucije koja je "kruna cjelokupne prošlosti", pa je u ovim postavkama malo ostalo mjesta za bilo što gdje se nije mogla uočiti nit koja povezuje povijest "naših naroda i narodnosti" s komunističkom revolucijom. U tom kontekstu u nastavi povijesti "bezlični srednji vijek" bio je u cijelosti drugorazredno pitanje, a dosljedno tomu i uloga i značenje hercega Stjepana Kosače.

O značenju srednjovjekovlja u nastavi povijesti govore i sljedeće činjenice. Naime, prema nastavnom planu i programu za srednje škole iz 1980. godine povijesna razdoblja od staroga vijeka do početka $\mathrm{Pr}-$ voga svjetskog rata učila su se u prvome razredu, a u drugome razredu razdoblje nakon Prvoga svjetskog rata. Na kraju ovoga nastavnog plana i programa vezano uz predmet povijesti stoji: "dvije osnovne cjeline programskih sadržaja (Kulturno nasljeđe Starog vijeka i Doba feudalizma) date su da bi učenici jasnije uočili kontinuitet u razvitku svjetske kulture i civilizacije i da bi bolje razumjeli novovjeku istoriju. Zato te cjeline treba obraditi u najsažetijem pregledu..."21 $\mathrm{Za}$

2-3. Raspored četiri navedena naziva časopisa izmjenjivali su se na naslovnici. O časopisu više: DAMIR AgIčrć, "Pet godina časopisa Povijest u nastavi (2003-2007. godine). Bibliografija, broj 1-10", u: Povijest u nastavi, 11, Zagreb, 2008., str. 5.

18 "Zajednička programska jezgra za nastavu povijesti", str. 3, 13.

19 Isto, str. 11.

20 Isto.

21 Nastavni plan i program zajedničke vaspitno-obrazovne osnove za srednje usmjereno obrazovanje i vaspitanje, Republički prosvjetno-pedagoški zavod, Sarajevo, 1980., str. 166. 
srednjovjekovno razdoblje stoji sljedeća napomena: "Naše zemlje u feudalno doba treba obraditi sintetički. Dovoljno je da se naše srednjovjekovne države samo bliže hronološki i teritorijalno odrede i da se ukaže na zajedničke karakteristike i specifičnosti njihovog razvitka."22 Prema ovim uputama, povijest staroga i srednjega vijeka treba učiti zato da bi se bolje razumjela "novovjeka istorija", pa zato "te cjeline treba obraditi u najsažetijem pogledu". Stoga imajući ovo u vidu, jasno je da taj školski sustav nije držao shodnim razviti bilo kakvu temu o hercegu Stjepanu.

Kako je pri provođenju takvih zadataka u nastavi povijesti glavnu ulogu igrao nastavnik, smatramo uputnim reći i nekoliko riječi o njegovoj ulozi i sposobnostima koje su mu bile potrebne za "uspješno" poučavanje nastavnih sadržaja. Tako se primjerice u djelu sovjetskoga metodičara A. I. Straževa Metodika nastave istorije, koje je nakon njegove smrti prevedeno i objavljeno u Sarajevu, navodi da se povijest ne može predavati "ako nastavnik nije naoružan dijalektičkim i istorijskim materijalizmom, marksističko-lenjinističkim shvatanjem istorije, ako nije čovjek koji iskreno i vatreno propagira komunističke ideje". ${ }^{23}$ Odgovor na pitanje kakav je trebao biti idealan nastavnik povijesti možda najbolje ilustrira mišljenje tadašnjih "stručnjaka" za školstvo. Tako u časopisu Nastava istorije u osnovnoj školi jedan od autora, govoreći o odgojnoj ulozi nastave povijesti, navodi kako nastavnik povijesti "treba, pre svega, da bude svestan svoga velikog zadatka:..." te da "nijedan nastavnik nema one mogućnosti da ulije ubedjenja i revolucionarna nadahnuća u srca mladih ljudi kao što to ima nastavnik istorije", ${ }^{24}$ i zaključuje: "Bratstvo i jedinstvo odigralo je, kao što smo rekli, kao što se zna, presudnu ulogu u našoj revolucionarnoj borbi. Nastavnik istorije baš zato što mora biti, baš on, idejno prekaljen i nadahnut idejom bratstva i jedinstva (bez obzira da li predaje istoriju u Mariboru, Sisku, Mostaru, Cetinju, Kragujevcu ili Bitolju), [treba] voditi računa o tome kakve nam mogućnosti daje nastava istorije za razvijanje osećanja bratstva i jedinstva." ${ }^{25} \mathrm{Je}-$

22 Isto, str. 167.

23 A. I. StražEv, Metodika nastave istorije, Zavod za izdavanje udžbenika, Sarajevo, 1965., str. 228.

24 Vukašin RAdonjIć, "Vaspitna uloga nastave istorije u osnovnoj školi", u: Nastava istorije u osnovnoj školi, Savezni zavod za proučavanje školskih i prosvetnih pitanja. Grupa za opšteobrazovne škole, Beograd, 1962., str. 24. Isto, str. 27. 
dan drugi autor, gimnazijski profesor u Zagrebu, čak otvoreno kaže da je povijest politički predmet, ${ }^{26}$ iz čega zaključujemo da je tadašnjim ideolozima škola služila uglavnom za "odgoj" i "preodgoj" djece i mladeži, pri čemu je nastava povijesti igrala najvažniju ulogu. Zato je ta nastava i bila koncipirana tako da je komunističkoj ideologiji i jugoslavenskoj komunističkoj revoluciji bilo posvećeno vremena i gradiva više nego svim stoljećima ljudskoga postojanja. Ako to tako sagledavamo, herceg Stjepan Kosača i njegova Humska zemlja, kao i njegovo doba uopće, bili su samo kamenčić u povijesnom mozaiku koji se izgubio u povijesnim bespućima komunističkoga režima.

\section{Herceg Stjepan u bh. udžbenicima}

Iz navedenih nastavnih planova i programa dade se naslutiti kako je srednjovjekovna povijest u ondašnjim udžbenicima sažeto prikazana pa time i podatci o životu i djelovanju hercega Stjepana. No, zanimljivo je vidjeti da je u starijim udžbenicima bilo više podataka o hercegu Stjepanu, dok su od 60-ih godina podatci o njemu u udžbenicima bitno reducirani. Ono što je također evidentno jest da svi udžbenici navode da je po njegovoj tituli nazvana Hercegovina i njezin pad pod osmanlijsku vlast, dok su drugi podatci koje spominju vezano uz njega različiti kako opsegom tako i sadržajem. Treba imati na umu da se u ovim udžbenicima pod nacionalnom poviješću obrađivala povijest "naših naroda" odnosno povijest Južnih Slavena. Tako podatke o hercegu Stjepanu nalazimo u nastavnim cjelinama s naslovima "Propadanje feudalnih država", "Pad naših srednjovjekovnih država", "Tursko osvajanje jugoslovenskih zemalja", "Slom feudalnih država Južnih Slovena" i slično u sklopu čega je pad Hercegovine nekada naznačen posebnim podnaslovom a negdje je obrađen pod naslovom "Pad Bosne i Hercegovine". U nekim nastavnim jedinicama pojedinih udžbenika postoji i posebni podnaslov "Postanak Hercegovine".

Zbog usporedbe broja podataka o hercegu Stjepanu u udžbenicima iz različitih godina, krenut ćemo od najstarijega, nama dostupnoga, udžbenika, a to je već spomenuta knjiga autora Ante Babića, u kojoj nalazimo brojne podatke o hercegu Stjepanu. U ovoj knjizi herceg Stjepan spominje se u nastavnoj cjelini koja obrađuje "Propadanje

26 Ljubomir Kargačin, "Ciljevi i zadaci nastave istorije", u: Nastava istorije u osnovnoj školi, Savezni zavod za proučavanje školskih i prosvetnih pitanja. Grupa za opšteobrazovne škole, Beograd, 1962., str. 30. 
feudalnih država", i to u trećoj nastavnoj jedinici s naslovom "Propadanje bosanske države". Naime, autor jedan odlomak posvećuje temi "Vjerska gonjenja bogumila" u kojemu navodi kako je bosanski kralj Stjepan Tomaš bio priznat za kralja nakon što se odrekao "bogumilstva" i počeo progoniti pripadnike Crkve bosanske. Nakon toga stoji: "Nastala su velika vjerska progonstva. Narod je u masama bježao iz svoje domovine. Godine 1450 četrdeset starješina bogumilske bosanske crkve s mnogobrojnim narodom pobjeglo je iz Bosne i sklonilo se u Humskoj zemlji kojom je tada vladao Stjepan Vukčić, gorljivi pristalica bogumilstva i neprijatelj kralja Stjepana Tome". ${ }^{27} \mathrm{U}$ odlomku s naslovom "Slom bosanske feudalne države" autor, između ostaloga, navodi: u vrijeme upada Osmanlija u Bosnu "bjesnio je krvav rat između kralja Stjepana Tome i hercega Stjepana Vukčića, između hercega i njegovih sinova, između kralja i njegovog brata, te između pojedine male i velike vlastele". ${ }^{28} \mathrm{U}$ istoj nastavnoj jedinici dva dijela posvećena su Hercegovini. U prvome "Postanak Hercegovine" piše:

"Od kraja XIV stoljeća izdvajalo se iz bosanske države područje Humske zemlje ili Zahumlje koje je, uglavnom, zahvatalo sliv rijeke Neretve. U doba Tvrtka I Humska zemlja pripadala je njegovim vazalima, braći Sankovićima. Iza Tvrtkove smrti, najveći dio Humske zemlje prigrabio je bosanski vojvoda Sandalj Hranić koji je osvajanjem priključio tome području krajeve oko gornje Drine, Čehotine i Lima. Kad je godine 1435 umro vojvoda Sandalj, naslijedio je čitavu njegovu zemlju njegov sinovac Stjepan Vukčić Kosača koji je taj teritorij znatno proširio. Sinovima Pavla Radenovića oteo je Trebinje sa susjednim župama; u Dalmaciji je osvojio Poljičku župu sa gradom Omišem, a Mlečanima je oteo gradove u Crnogorskom primorju. Sa bosanskim kraljevima Tvrtkom II i Stjepanom Tomom bio je u stalnom neprijateljstvu te je svoju zemlju proširivao na račun bosanskog državnog područja, kad god bi mu se ukazala prilika za to. Bio je odlučan bogumil te je pod svoju zaštitu primao bogumile koji su zbog vjerskih progona morali da bježe iz Bosne. Da bi se zaštitio od svojih mnogobrojnim neprijatelja, bosanskog kralja, Mlečana i Dubrovčana, on je priznao vrhovnu vlast turskog sultana, plaćao mu godišnji danak i uz pomoć Turaka učinio se stvarno nezavisnim o bosanskom kralju. Da bi i vidnim znakom obilježio svoju nezavisnost prema Bosni, on se je godine 1448 proglasio 'hercegom od Sv. Save', a po tome se je i čitava njegova oblast počela nazivati Hercegovinom. (Prvi put je taj naziv zapisan godine 1454)."29

27 Anto BABIć, Istorija naroda Jugoslavije I. dio, "Svjetlost" Državno izdavačko preduzeće Bosne i Hercegovine, Sarajevo, 1946., str. 127.

28 Isto, str. 128.

29 Isto, str. 130. 
Posljednji dio ove nastavne jedinice glasi "Pad Hercegovine", u kojemu se kaže:

\begin{abstract}
"Herceg Stjepan nije pomagao bosanskog kralja u času turskog napada na Bosnu. No, bez obzira na njegovo držanje, Turci su 1465 napali na Hercegovinu i zauzeli najveći dio zemlje. Ostatak su naslijedili sinovi hercega Stjepana, Vladislav i Vlatko. No i Hercegovina je bila razrivena istim razdorima kao i Bosna. Vladislav je tražio pomoći od Mađara, a Vlatko od Mlečana. Mlečani zaposjednu Hercegovačko primorje i Neretvansku krajinu, a Turci zavladaju čitavim unutrašnjim područjem. Herceg Vlatko držao je još neko vrijeme grad Novi sa okolnim krajevima. Godine 1482 Turci su zauzeli Novi sa posljednjim ostacima Hercegovine. Bosna i Hercegovina spojene su tada u jedno područje, jedan turski pašaluk." ${ }^{30}$
\end{abstract}

Također više podataka o ovim događajima kao i o hercegu Stjepanu navodi se u udžbeniku Vladimira Babića, tiskanom u Zagrebu 1950. godine, u kojemu se herceg naziva Stefan, a ne Stjepan. Naime, u nastavnoj cjelini "Pad naših feudalnih država pod Turke", a u nastavnoj jedinici "Pad Bosne i Hercegovine" autor navodi: "U isto vrijeme kada su Turci natjerali Tvrtka na plaćanje danka, počeo im je plaćati harač i nasljednik Sandaljev Stefan Vukčić Kosača. On je u početku svoje vladavine vodio teške borbe za oblast na desnoj obali Neretve s hrvatskim banom Matkom Talovcem, s nepokornim humskim velikašima i sa sinom Pavla Radenića Radoslavom Pavlovićem, koji je htio da povrati oblasti, što ih je oteo Sandalj, kad mu je ubio oca. Stefan je dobio pomoć od Turaka, pobijedio svoje protivnike i oteo od Radoslava Trebinje, ali je postao turski vazal."31 Nadalje, autor piše kako se bosanski kralj Stjepan Tomaš približava Mađarima i Zapadu, te "prelazi na katoličku vjeru". Opisujući situaciju u Bosni autor navodi kako "u Bosnu dolazi papina inkvizicija pod rukovodstvom franjevaca i dominikanaca... Inkvizitori su slušali papin nalog i savjesno vršili svoj krvnički posao. Uvodeći rimsku vjeru i odvajajući narod od njegove narodne crkve, nametali su crkvene dažbine i nemilo tlačili narod. Mnogo naroda sa 40 bogumilskih starješina pobjeglo je u oblast Stefana Vukčića, koji je bio bogumil i neprijatelj kralja Tomaša. Ali i ondje su nastale slične prilike. I Stefan je tražio oslon na Zapadu, pa je pregovarao s kraljem južne Italije Alfonsom o savezu protiv Turaka, a on mu je, mjesto pomoći, poslao franjevce da krste 'heretike'. Tako se Zapad brinuo za spas kršćana na Balka-

30 Isto, str. 130-131.

31 Vladimir Babić, Povijest za VI. razred sedmogodišnje škole i II. razred gimnazije, Školska knjiga, Zagreb, 1950., str. 90. 
nu!"32 U ovome se odlomku zapaža komunističko-ateistička ideologija, što dobro ilustrira tvrdnja da su inkvizitori "slušali papin nalog i savjesno vršili svoj krvnički posao". Nadalje u ovome udžbeniku stoji kako je herceg Stjepan bio turski vazal, te je uz pomoć Turaka postao neovisan o bosanskome kralju, da je proširio svoju vlast na Poljičku župu s Omišem i Zetsko primorje, ratovao s Dubrovčanima te s namjerom da istakne svoj neovisan položaj prema bosanskome kralju "prozvao se 1448. hercegom od sv. Save, jer je u njegovoj vlasti bilo Mileševo, gdje je bio sahranjen Sava Nemanjić". ${ }^{33}$ Nadalje, govoreći o padu Bosne a zatim i Hercegovine pod osmanlijsku vlast autor navodi:

"Herceg Stefan nije pomogao Bosni, kad su na nju napali Turci, ali kad je kralj Matija sklopio savez s Mlečanima protiv Turaka, pridruži se on njima, te pomagaše Matiji pri zauzimanju Jajca i u prodoru dolinom Neretve. Ali mu zato Turci već iduće godine zauzeše prijestolnicu Blagaj, a Mlečani nato zauzeše Krajinu s ušćem Neretve. Kad je on 1466. umro bili su i njegovoj zemlji odbrojani dani. Od njegovih sinova Stefan je primio islam, Vladislav je nastojao da se održi pomoću Madžara, a Vlatko pomoću Mletaka. Vladislav se najposlije preseli u Slavoniju, a Vlatku oteše saveznici Mlečani veći dio posjeda, tako da mu je ostao samo Novi s okolinom. Ali kad se pokušao odmetnuti, oduzeše mu Turci i taj grad 1482. Tako je pao i posljednji ostatak sredovječne Bosne u turske ruke." ${ }^{34}$

Mnogo manje podataka o Stjepanu Kosači nalazimo u udžbeniku Miloša Perića iz 1956. godine. Naime, u nastavnoj jedinici "Pad bosanske države pod Turke", autor se dotaknuo teme o odnosu bosanskoga kralja prema Crkvi bosanskoj, te govori kako se kralj Stjepan Tomaš zbog osmanlijske opasnosti obraća rimskome papi koji traži od njega da se u Bosni iskorijeni "bogumilstvo" pa stoga Tomaš počinje progoniti pripadnike Crkve bosanske koji se onda sklanjaju kod Stjepana Kosače u Humsku zemlju. ${ }^{35} \mathrm{U}$ posljednjem dijelu ove nastavne jedinice tema je "Pad Hercegovine" gdje stoji sljedeće:

"Velikog vojvodu Sandalja Hranića naslijedio je njegov sinovac Stjepan Vukčić Kosača. On je nastojao da se potpuno osamostali. 1448 godine izdvojio je svoju oblast iz bosanske države i nazvao se hercegom. Zato se ta oblast i nazvala Hercegovina. Stjepan Vukčić je priznavao vrhovnu vlast Turaka. Iza pada Bosne počela se i Stjepanova oblast smanjivati. Otkidali su

32 Isto, str. 91.

33 Isto.

34 Isto, str. 92-93.

35 Miloš Perić, Istorija za V razred narodne šestogodišnje škole, Izdavačko preduzeće "Veselin Masleša", Sarajevo, 1956., str. 108 (ćir.). 
komad po komad Turci, Mađari i Mlečani. Mlečani su zauzeli Primorje, a

Turci ostale krajeve 1482 godine." ${ }^{136}$

"Pad naših srednjovjekovnih država" nastavna je cjelina koju su također predviđali i nastavni planovi i programi iz 60-ih godina 20. stoljeća. ${ }^{37} \mathrm{U}$ sklopu ove teme govori se i o padu Hercegovine pod osmanlijsku vlast gdje se donose podatci o hercegu Stjepanu Vukčiću Kosači. No, za razliku od navedenih udžbenika iz poslijeratnoga vremena, u udžbenicima od 60-ih godina nadalje nalazimo mnogo manje podataka o hercegu Stjepanu. Tako u udžbeniku za sedmi razred osnovne škole u nastavnoj jedinici s naslovom "Propast Bosanskog kraljevstva" tema jednoga odlomka jest "Kako je postala Hercegovina" u kojemu stoji:

"U međusobnom oduzimanju posjeda kroz niz godina najviše je bila ojačala porodica Hranića. Sandalja Hranića naslijedio je bio sinovac Stjepan Vukčić. On je gospodario ne samo Humom već Podrinjem i Krajinom između Cetine i Neretve, pa Trebinjem i nekim gradovima u Zeti. U borbi protiv bosanskog kralja oslanjao se na Turke i postao je sultanov vazal. Da bi pokazao da ne ovisi o bosanskom kralju, proglasio se godine 1448. za 'hercega od sv. Save'. To je početak Hercegovine." ${ }^{18}$

$\mathrm{U}$ istoj nastavnoj jedinici o hercegu Stjepanu nalazimo podatke i u dijelu s naslovom "I Hercegovina je pala" u kojemu se kaže: "Turci nisu poštedjeli ni hercega Stjepana. Kad se u zadnji čas bio pomirio $s$ bosanskim kraljem, Turci su počeli otimati komad po komad njegove države. S druge su mu strane Mlečani oteli Krajinu. Kada su Turci njegovu sinu oteli godine 1482. grad Novi u Boki Kotorskoj, pao je i posljednji ostatak Hercegovine." ${ }^{39}$

U bh. udžbeniku Ivana Božića, iz 60-ih godina 20. stoljeća, nalazimo sljedeće podatke. U temi "Tursko osvajanje jugoslovenskih zemalja" u dijelu s naslovom "Pad Bosne, Hercegovine i Crne Gore" navodi se: "Stjepan Vukčić Kosača (1435-1466) proširio je, oslanjajući se na Turke, posjede svoje kuće, ratovao je i protiv bosanskog kralja i kao samostalni vladar uzeo 1448. god. titulu 'herceg od svetog Save'. Ze-

36 Isto, str. 109.

37 Nastavni plan i program za osnovne škole, Svjetlost, Sarajevo, ${ }^{2} 1960$. , str. 164; Nastavni plan i program za osnovne škole, Zavod za izdavanje udžbenika, Sarajevo, 1964., str. 193.

38 Olga SAlzer, Istorija za VII razred osnovne škole, Zavod za izdavanje udžbenika, Sarajevo, 1961., str. 22.

39 Isto, str. 22-23. 
mlja kojom je vladao nazvala se po njegovoj tituli Hercegovina." ${ }^{40}$ Autor nadalje govori o padu Bosne i pogubljenju bosanskoga kralja te piše da je Stjepan Kosača: "izbjegao njegovu sudbinu", te da su "Turci 1465. god. zauzeli veći dio njegovih zemalja. Ostao mu je samo uzani pojas uz more s gradovima Novim i Risnom u Boki Kotorskoj. Taj mali dio hercegove zemlje Turci su osvojili od njegovog nasljednika pred sam kraj 1481. god."41 $\mathrm{Na}$ kraju nastavne jedinice u "Podsjetniku" stoji, između ostaloga: "Stjepan Vukčić Kosača uzeo je 1448. god. titulu hercega, po kojoj se njegova oblast nazvala Hercegovina. Turci su zauzeli Bosnu 1463, najveći dio Hercegovine 1465, a njene ostatke (grad Novi) krajem 1481. god."42 Zanimljivo je da se u udžbenike iz iste godine a tiskanom u Beogradu nalazi mnogo više podataka o hercegu Stjepanu. Naime, u beogradskom udžbeniku iz 1961. u nastavnoj jedinici "Pojava Turaka i pad naših država pod tursku vlast" u dijelu "Pad Hercegovine i Zete" piše:

"Još početkom XV veka Sandalj Hranić je postao jedan od najmoćnijih velikaša u Bosni. On je bio skoro neograničeni gospodar na području 'od Prijepolja, Pljevalja i Nikšića do Cetinja'. Njega je nasledio Stepan Vukčić Kosača (1435.-1466. godine), koji se u svojoj politici oslanjao na Turke. Pošto se manastir Mileševo, gde je sahranjen sveti Sava, nalazio u sastavu njegove države, proglasio se 'hercegom od svetoga Save' po čemu je i cela njegova oblast dobila ime Hercegovina. Docnije je herceg napustio orijentaciju prema Turcima i počinje da se bori protiv njih, naročito posle pada Bosne. $U$ savezu sa Mađarima uspešno je odbijao turske napade. Ali, kad su Mađari s Turcima zaključili mir, herceg je morao da im plaća veliki danak. Posle smrti hercega Stepana njegovi su sinovi priznali tursku vlast. Ali, i pored toga, Turci su napali njihovu zemlju i osvojili je 1482. godine." ${ }^{143}$

S druge strane, u hrvatskome udžbeniku iz istih godina ti su događaji vrlo sažeti. Tako u jednome hrvatskom udžbeniku iz 1963. godine u nastavnoj jedinici s naslovom "Južnoslavenski narodi pod tuđinskom vlašću", stoji vrlo kratka opaska na pad Hercegovine. Naime, nakon što se autor kratko osvrnuo na pad Bosne i konstatacije "Bosna

40 Ivan BožIć, Istorija za VI razred osnovne škole, Zavod za izdavanje udžbenika, Sarajevo, 1965., str. 189 (ćir.).

41 Isto, str. 190.

42 Isto, str. 191.

43 Jovan Nešıć, Istorija. Udžbenik za VI razred osnovne škole, Zavod za izdavanje udžbenika Narodne Republike Srbije, Beograd, ${ }^{2}$ 1961., str. 140-141 (ćir.). 
'šaptom pade"' napisao je samo: "Doskora su je slijedile Hercegovina (1482) i Crna Gora (1499) - kako se od 15. st. nazivala Zeta." ${ }^{14}$

Više podataka o hercegu Stjepanu nalazimo u udžbeniku za drugi razred gimnazije iz 1969. godine u nastavnoj jedinici "Slom feudalnih država Južnih Slovena", a u dijelu koji obrađuje "Razjedinjenost Bosne" spominje se i herceg Stjepan: "Unutrašnje borbe su planule velikom žestinom poslije smrti Sandalja Hranića, koga je naslijedio sinovac Stefan Vukčić, a zatim i poslije smrti Tvrtka II, kada je na prijesto došao Tomaš (1443-1461). Iako je kralj Tomaš postao zet Stefana Vukčića, ipak je među njima stalno dolazilo do neprijateljstava. Pred sredinu XV v. njih dvojica su bili najmoćniji gospodari u Bosni jer su ostali feudalci tokom vremena pali pod uticaj jednog ili drugog. Stefan Vukčić je 1448, da bi naglasio svoju samostalnost prema kralju, uzeo titulu hercega, koja je u evropskom feudalnom svijetu dolazila odmah iza kraljevske. Po ovoj tituli prozvana je poslije turskog osvajanja čitava Stefanova zemlja Hercegovinom. Tu oblast Stefan Vukčić nije stvorio, već je samo očuvao i proširio."45 Također, u istome udžbeniku u nastavnoj jedinici s naslovom "Slom feudalnih država Južnih Slovena", a u dijelu koji obrađuje "Pad južnoslovenskih zemalja", herceg Stjepan spominje se u govoru o padu Bosne i padu Hercegovine. Autor navodi kako se kralj Stjepan Tomašević izmirio s hercegom Stjepanom, te nastavlja: "Snagu Bosne je u posljednjim godinama slabio i razdor između hercega Stefana i njegovog sina Vladislava, koji se sultanu obraćao za pomoć i dovodio Turke u Bosnu." ${ }^{146}$ Nadalje autor navodi kako je za vrijeme osmanlijskoga pohoda protiv Bosne osvojen i "najveći dio teritorije hercega Stefana", ali je herceg odmah nakon povlačenja Osmanlija počeo oslobađati svoje gradove, te da uspostavljanje Jajačke i Srebreničke banovine nije pomoglo hercegu Stjepanu. Autor navodi: "Hercegovu zemlju to ipak nije spaslo. Najveći dio zauzeli su Turci 1465, a grad Novi (Herceg-Novi) i uzak pojas zemljišta u primorju držali su se pod hercegom Vlatkom, nasljed-

44 Ivo Makek, Prošlost i sadašnjost 1. Udžbenik historije za VI razred osnovne škole, Školska knjiga, Zagreb, 1963., str. 175.

45 Sima M. Ćirković, Istorija za II razred gimnazije, Zavod za izdavanje udžbenika, Sarajevo, ${ }^{2} 1969$., str. $100-101$. Na početku stoji da je ovaj udžbenik rađen prema udžbeniku istoga autora s naslovom Historija ljudskog društva $i$ kulture koji je tiskan u izdanju Zavoda za izdavanje udžbenika SRS, a usklađen je prema nastavnom planu i programu za gimnazije u SRBiH.

Isto, str. 102. 
nikom Stefana Vukčića. Vlatko Hercegović se sa svojom vlastelom održao do početka 1482, kada je predao Novi i sasvim izgubio zemlje naslijeđene od oca. ${ }^{147}$ Među pitanjima na kraju lekcije nalazi se i ovo: "Da li je Hercegovina nastala kad je Stefan Vukčić uzeo titulu hercega?"48 Zanimljivo je uočiti kako se u beogradskom udžbeniku iz 1969. godine od istoga autora, prema kojemu je rađen i ovaj udžbenik za gimnazije u $\mathrm{BiH}$, herceg navodi kao Stjepan a u ranije spomenutom sarajevskom izdanju istoga autora kao Stefan. ${ }^{49}$

Na području Bosne i Hercegovine 70-ih i 80-ih godina 20. stoljeća u osnovnim školama u uporabi je bio udžbenik čija je autorica Emina Omanović. U tri pregledana udžbenika ove autorice nalazimo identične odlomke u kojima se spominje herceg Stjepan, a razlika je u naslovima nastavnih jedinica. Tako u njezinu udžbeniku iz 1974. godine u nastavnoj jedinici "Pad Bosne, Hercegovine i Crne Gore pod tursku vlast" u dva dijela nalazimo podatke o hercegu Stjepanu, i to najprije u dijelu s naslovom "Postanak Hercegovine" u kojemu stoji: "Unutrašnji neredi, koji su od kraja XIV vijeka sve više zahvatali bosansku državu, najjače su se osjećali u južnim njenim krajevima, koji su bili i jače izloženi turskim napadima. Gospodar ovih oblasti, Stjepan Vukčić Kosača proširio je posjede, te kao samostalni vladar 1448. godine uzeo titulu Herceg od sv. Save. Zemlja kojom je vladao nazvala se po njegovoj tituli Hercegovina." ${ }^{50}$

Uz ovaj dio stoji i slika srednjovjekovnoga grada Blagaja s pojašnjenjem da se radi o ruševinama ovoga grada te se kaže: "U ovoj snažnoj tvrđavi kod izvora Bune živio je herceg Stjepan Vukčić Kosača." ${ }^{11}$ Nakon toga tema sljedećega dijela je "Pad Bosne i Hercegovine". U

47 Isto, str. 103.

48 Isto, str. 104.

49 Primjerice u beogradskom udžbeniku nalazimo: "Naročito ogorčeni sukobi bili su između kralja Tomaša (1444-1461) i Stjepana Vukčića Kosače (14351466), naslednika Sandalja Hranića, koji je 1448. god. uzeo titulu "herceg od svetog Save". Također: "Iz vremena turskog osvajanja potiče i naziv 'Hercegovina' za zemlje kojima je gospodario još Sandalj Hranić. Taj naziv je nastao prema tituli hercega Stjepana". Sima M. ĆInković, Historija ljudskog društva i kulture (od XII do XVIII veka) za učenike II razreda gimnazije društveno-jezičkog smjera, Zavod za izdavanje udžbenika Socijalističke Republike Srbije, Beograd, ${ }^{2} 1964$., str. 97.

50 Emina Omanović, Istorija-povijest za VI razred osnovne škole, IP "Svjetlost" OOUR Zavod za udžbenike, Sarajevo, 1974., str. 88-89 (ćir.).

51 Isto, str. 89. 
njemu autorica nakon opisa pada Bosne navodi: "Turci nisu poštedjeli ni Hercega Stjepana. Godine 1465. zauzeli su veći dio njegovih zemalja. Ostao mu je samo uzani pojas zemljišta u primorju, sa gradovima Novim i Risnom u Boki Kotorskoj. Ovako smanjenu i razrivenu oblast ostavio je Herceg Stjepan svome sinu Vlatku, koji ju je držao sve do početka 1482. godine. Te godine Turci osvojiše Novi, i time pod tursku vlast pade i posljednji ostatak nekadašnje moćne bosanske države." 52

U udžbeniku iz 1981. godine nalazimo iste sadržaje s razlikom da su navedeni u dvije nastavne jedinice. Naime, na kraju nastavne jedinice "Uspon bosanske feudalne države" nalazimo identičan tekst kao u udžbeniku iz 1974. godine u dijelu s istim naslovom "Postanak Hercegovine". Jedina razlika u tekstu jest što ovoga puta autorica navodi da je Stjepan Kosača uzeo titulu "Herceg" a ne "Herceg od sv. Save", kako je stajalo u ranijem udžbeniku. ${ }^{53}$ Također, autorica u ovome izdanju navodi pojašnjenje titule herceg: "feudalac koji upravlja jednom oblasti - u ovom slučaju Hercegovinom. To je njemačka titula, koja ima značenje 'vojvoda'."54 U drugoj nastavnoj jedinici u istome udžbeniku obrađena je tema "Turska osvajanja Srbije, ${ }^{55}$ Bosne, Hercegovine i Crne Gore", a u njemu je tekst o padu Hercegovine (podnaslov glasi "Pad Bosne i Hercegovine") doslovce isti kao i u udžbeniku ove autorice iz 1974. godine. ${ }^{56} \mathrm{U}$ udžbeniku iste autorice iz 1985. godine nazivi nastavnih jedinica isti su kao i u udžbeniku iz 1981., a sadržaj tekstova koji spominju hercega Stjepana identični su izdanjima iz 1974. i 1981. godine. ${ }^{57}$

52 Isto.

53 Emina Omanović, Istorija-povijest za VI razred osnovne škole, "Svjetlost" OOUR Zavod za udžbenike i nastavna sredstva, Sarajevo, ${ }^{8} 1981$., str. 73 (ćir.).

54 Isto.

55 Napominjemo da je u udžbeniku iz 1974. posebno bila nastavna jedinica o padu Srbije pod Turke, a u drugoj je nastavnoj jedinici obrađen pad Bosne, Hercegovine i Crne Gore.

56 Usp. E. Omanović, Istorija-povijest za VI razred osnovne škole, "Svjetlost" OOUR Zavod za udžbenike i nastavna sredstva, Sarajevo, ${ }^{8} 1981 .$, str. 95; E. OMANOvić, Istorija-povijest za VI razred osnovne škole, IP "Svjetlost" OOUR Zavod za udžbenike, Sarajevo, 1974., str. 88-89.

57 Emina Omanović, Povijest. Udžbenik za šesti razred osnovne škole, "Svjetlost" OOUR Zavod za udžbenike i nastavna sredstva, Sarajevo, ${ }^{2} 1985$., str. 84, 111 (ćir.). 
Uvidom u tekstove navedenih udžbenika evidentno je da se navodi u udžbenicima razlikuju, osim po opsegu, i po naglascima na pojedine činjenice. Naime, u usporedbi navedenih podataka o hercegu Stjepanu $\mathrm{u}$ analiziranim udžbenicima nalazimo sljedeće sličnosti. Svi autori navode da je Stjepan Kosača uzeo titulu hercega 1448. (navodeći da je razlog tome njegova volja da pokaže neovisnost o bosanskome kralju) i da se po njegovoj tituli nazvala Hercegovina. Razlika je jedino u tome što neki autori navode samo titulu "herceg", a drugi "herceg od sv. Save". Također, u svim udžbenicima naveden je i konačan pad Hercegovine pod osmanlijsku vlast.

Svi ostali podatci variraju od jednoga do drugoga udžbenika. Kako je spomenuto, stariji udžbenici donose mnogo više podataka o hercegu Stjepanu, a u njima se, za razliku od novijih smatralo bitnim spomenuti da je herceg pružao zaštitu pripadnicima Crkve bosanske, gdje ga decidirano nazivaju "bogumilom", dok se u udžbenicima od 60-ih godina nadalje ne govori o njegovu odnosu s Crkvom bosanskom, pa ni o njegovoj vjerskoj pripadnosti. Ako gledamo samo udžbenike od 60-ih godina koji su pisani za osmogodišnju školu i gimnaziju, uočavamo sljedeće razlike. Ne spominju svi godine hercegova "vladanja" (samo u jednom udžbeniku je navedeno), a ni činjenicu da je naslijedio Sandalja Hranića, kao ni posjede koje je držao (navedeno u dva udžbenika), a samo jedan autor navodi da je njegov grad Blagaj i donosi sliku grada. Također, samo u gimnazijskome udžbeniku nalazimo da je hercegov zet bio bosanski kralj Stjepan Tomaš, ali se ne navodi ime njegove kćeri, bosanske kraljice Katarine, dok se samo u istom udžbeniku spominju njegovi sinovi Vladislav i Vlatko. U udžbenicima za osnovnu školu iz 70-ih i 80 -ih godina navodi se da ga je naslijedio sin Vlatko, dok se to u ranijim udžbenicima ne navodi.

Puno sažetije nalazimo (ali i neke netočne podatke) u udžbenicima koji su bili u uporabi 90 -ih godina prošloga stoljeća. Naime, kako u to vrijeme Hrvati u BiH nisu imali svoje domaće udžbenike, služili su se uglavnom udžbenicima iz Republike Hrvatske, pa ćemo za prikaz podataka u tim udžbenicima o hercegu Stjepanu navesti sadržaje iz dva udžbenika (jedan za osnovnu školu, a drugi za gimnaziju), koji su 90-ih godina bili korišteni u nekim školama u Hercegovini koje su radile po hrvatskom nastavnom planu i programu. U udžbeniku Ive Makeka u nastavnoj jedinici (na četiri i pol stranice) s nazivom "Bosna u srednjem vijeku" u podnaslovu "Slabljenje Bosne i njezin pad" nakon govora o tomu da je 1408. ugarsko-hrvatski kralj Sigismund poveo križarsku vojnu na Bosnu autor navodi: "Veći dio bosanskih 
velikaša, obeshrabrenih Žigmundovom nadmoćnošću i okrutnošću, udružio se protiv njega s Turcima. A Turci nisu propustili priliku da se ukorijene u Bosni i da razaraju njezinu otpornu snagu. U takvim je okolnostima Stjepan Vukčić Kosača u južnoj Bosni 1448. godine uzeo naslov hercega (vojvode), čime je istakao svoju nezavisnost. Otada se taj dio Bosne zove - Hercegovina." ${ }^{58}$ Nakon ovoga teksta navodi se pitanje: "Što ste upamtili o počecima Hercegovine?"59 Iz navoda vidimo da autor Hercegovinu smatra "južnom Bosnom" i da nema spomena o Humskoj zemlji.

U gimnazijskome udžbeniku u nastavnoj jedinici s naslovom "Bosna u srednjem vijeku" (na tri stranice većega formata) u posljednjem (trećem) dijelu, nakon što je navedeno da je Bosna pala 1463. godine te da je posljednji bosanski kralj Stjepan Tomašević pogubljen, spominje se herceg Stjepan. Taj odlomak glasi: "Područje kojim je upravljao nećak Hrvoja Vukčića Hrvatinića, Stjepan Vukčić Kosača, nazvano Hercegovina po tituli hercega što ju je uzeo 1448., nisu Turci zauzeli tada, već 1482 . No, padom Ključa i pogibijom posljednjega kralja prestala je postojati srednjovjekovna bosanska država." ${ }^{\prime 60} \mathrm{Na}$ kraju ovoga dijela nalazi se i pitanje: "Po čemu je Hercegovina dobila ime?"61 Kako vidimo, navedeni odlomak donosi veoma šture podatke o hercegu Stjepanu, a uz to i pogrješne (umjesto Sandalja Hranića čiji je nećak bio herceg Stjepan, autori navode Hrvoja Vukčića Hrvatinića).

\section{Herceg Stjepan Kosača u imenima ulica i institucija hercego- vačkih gradova i općina}

U kontekstu razmatranja recepcije hercega Stjepana Vukčića Kosače u Hercegovini zanimljivo je vidjeti koliko je hercegovačkih gradova i

58 Ivo Maкek, Povijest za VI. razred osnovne škole, Školska knjiga, Zagreb, ${ }^{4} 1995$., str. 93.

59 Isto.

60 Vladimir Posavec - Tatjana Medić, Stvaranje europske civilizacije i kulture (V.-XVIII. st.). Udžbenik povijesti za II. razred gimnazije, Profil, Zagreb, ${ }^{3} 1998$., str. 108. U svezi s ovim udžbenikom imamo neobičnu pojavu da se na korici i unutarnjoj referentnoj stranici pojavljuju različiti podatci, pa su tako različito poredani autori na navedenim mjestima, a i sam naslov na unutarnjoj stranici drukčiji je nego na korici (Povijest II. Udžbenik iz povijesti za II. razred gimnazije). Pomutnju stvara i godina izdavanja, pa u CIP katalogizaciji stoji 1997. a u impressumu 1998. godina.

61 Isto, str. 108. 
općina dalo ime ulici, trgu ili instituciji po ovom srednjovjekovnom velikašu. Zanimljiva je činjenica da nijedna od pet ulica u Hercegovini koje nose ime hercega Stjepana (Trebinje, Gacko, Posušje, Široki Brijeg i Ljubuški) nije imenovana u razdoblju komunističke Jugoslavije, nego u razdoblju od 1994. do 2015. godine. Ako znamo da je $\mathrm{u}$ to vrijeme komunistička ideologija bila prisutna u svim porama društva, nije čudno što su ulice i trgovi najčešće nosili imena raznih "narodnih heroja", pa je u tom kontekstu herceg Stjepan Vukčić Kosača za komunističke vlastodršce bio marginalna osoba. Imenovanje ulica u komunističkome razdoblju vrlo dobro ilustrira dokument od 12. lipnja 1945. koji potpisuje Martin Mencej, tadašnji pomoćnik ministra prosvjete DFJ, a koji je upućen republičkim ministarstvima prosvjete. U njemu stoji:

"Pojedini odbori i ustanove obraćaju se s pitanjem da li mogu podizati spomenike, škole, mostove i izvoditi slične radnje u spomen boraca Jugoslovenske armije.

Povodom toga smatramo potrebnim saopštiti da spomenutu inicijativu treba ne samo dozvoliti, već je treba preporučiti svim ustanovama i odborima. Plemenite pobude i korisne pothvate treba u tom pravcu svuda potsticati i starati se da se u narodu na što široj osnovi ostvaruju, te da se uspomena na zaslužne borce za slobodu naroda i takvim vidnim vanjskim znakom narodnog priznanja čuva, podržava i širi."62

Koliko je imenovanje ulica, trgova i ostalih objekata po "narodnim herojima" uzelo maha govori dokument iz 1952. godine. Naime, CK KPJ, Komisija za agitaciju i propagandu upućuje svim republičkim CK KPJ dopis sa sljedećim sadržajem:

"Većina naših preduzeća, zadruga i drugih ustanova i organizacija dobila je svoje nazive a najčešće prisvojila sebi ime istaknutog državnog i partiskog (sic!) rukovodioca, narodnog heroja ili neki krupni istoriski (sic!) datum.

Svakako da je to u mnogim slučajevima imalo razloga i smisla. (Ako se na pr. radi o jednom preduzeću za koje je na neki način vezana ta ličnost.) Međutim, neosporno je da se tu otišlo do nepotrebne širine i u mnogim slučajevima izgubilo svaki kriterij, te se i najsitnijoj radionici, i svakoj radnoj zadruzi moralo po svaku cenu naći neko ime, (postalo je nekako nezgodno da se radna zadruga, na pr. zove imenom sela na čijem je tlu nikla).

Potrebno je na čitavoj liniji naših ustanova, preduzeća, zadruga, društava itd. ovo pitanje prodiskutovati, revidirati i svesti stvar na pravu meru. Treba još jednom obratiti pažnju na čišćenje preostalih sovjetskih naziva. (Ovih je naziva ostalo najčešće kod ulica, koje su neke u periodu iza oslobođenja, po više puta menjale imena). Ovaj posao treba izvršiti temeljito, kako bi se

62 B. Doknić - M. F. Petrović - I. Hofman (prir.), Kulturna politika Jugoslavije 1945-1952. Zbornik dokumenata, str. 247 (dokument br. 95). 
stalno posle toga sa menjanjem imena i naziva, a samo izuzetno, ubuduće, treba neke specijalne nazive davati za pojedine institucije ili organizacije. AJ;507, VIII,I-(1-41)(K-2)"63

Zanimljivo je uočiti kako u ovom dokumentu stoji kako treba "obratiti pažnju na čišćenje preostalih sovjetskih naziva", a recimo Lenjinovo ime ostalo je u nazivima ulica mnogih naših gradova sve do Domovinskoga rata.

Vratimo se imenovanju ulica u hercegovačkim gradovima i općinama koje nose ime hercega Stjepana. Prema podatcima iz Službenih glasnika hercegovačkih gradova i općina, na području današnje Hercegovine najranije je imenovana ulica hercega Stjepana u Trebinju. Naime, Odlukom o određivanju naziva naselja, ulica, trgova, mostova, institucija i ustanova na području općine Trebinje u Trebinju je 1994. godine imenovana ulica Herceg Stefana ${ }^{64}$ Nakon toga, imenovana je ulica Herceg Stefana u Gacku 1996. godine. ${ }^{65}$ Nekoliko godina kasnije donesena je odluka o imenovanju Ulice Herceg Stjepana u Širokome Brijegu (10. ožujka 2004.), ${ }^{66}$ a godinu dana nakon toga, ulica hercega Stjepana Kosače imenovana je i u Posušju ${ }^{67}$ Posljednja je imenovana ulica hercega Stjepana Kosače u Ljubuškome, i to u siječnju 2016. ${ }^{68}$ No, valja spomenuti da je u Ljubuškome ranije bio imenovan trg hercega Stjepana Kosače, ${ }^{69}$ ali je ovom odlukom imenovana ulica koja nosi njegovo ime, a trg je preimenovan. ${ }^{70} \mathrm{~K}$ tomu

63 Isto, str. 249-250 (dokument br. 100).

64 Službeni glasnik opštine Trebinje, 4/1994., str. 56.

65 "Odluka o davanju naziva trgu i ulicama u naseljenom mjestu Gacko (prečišćen tekst)", članak 10, objavljen je naziv ulice Herceg Stefana. Službeni glasnik opštine Gacko, 2/1996., str. 3.

66 Službeni glasnik općine Široki Brijeg, 1/2004., str. 27.

67 Službeni glasnik općine Posušje, 1/2005., str. 2.

68 Službeni glasnik općine Ljubuški, 1/2016., str. 3.

69 http://www.ljubuski.ba/images/stories/setnja_ljubuskim/prostorni_plan/ mapa_ljubuskog_1280x853.jpg (18.4.2016.).

70 Valja spomenuti da "je od 2003. godine Ljubuški imao 103 ulice, 6 trgova i 1 park, a sada novim prijedlogom 56 naziva ulica je promijenjeno, 36 naziva ulica ukinuto, a novoimenovano 20 ulica". O tome kao i javnoj raspravi o novome imenovanju ulica i trgova u Ljubuškome, održanoj 12. listopada 2015., mogu se vidjeti podatci na: http://www.radioljubuski.ba/ ljubuskadogadnaj5/17479-odrzana-javna-rasprava-o-nazivima-ulica-trgova-i-parkova-u-ljubuskom-foto.html (18. 4. 2016.). 
dodajmo i instituciju Hrvatski dom "herceg Stjepan Kosača" u Mostaru, koja je imenovana 1994. godine. ${ }^{71}$

Što se tiče obitelji Kosača zanimljiva je činjenica da je najomiljenija bosanska kraljica Katarina Kosača Kotromanić. Naime, više je mjesta u Hercegovini posvetilo ulicu ili trg ovoj najpoznatijoj bosanskoj kraljici, kćeri hercega Stjepana (Mostar, ${ }^{72}$ Široki Brijeg, ${ }^{73}$ Ljubuški ${ }^{74}$ Posušje, ${ }^{75}$ Čapljina, ${ }^{76}$ Neum, ${ }^{77}$ Tomislavgrad, ${ }^{78}$ Čitluk i Bijakovići $\left.{ }^{79}\right)$. Također, osim ulice u Mostaru, u ovome gradu kraljica Katarina dobila je i spomenik ispred Hrvatskoga doma "herceg Stjepan Kosača", te galeriju u Hrvatskome domu "herceg Stjepan Kosača". Spomenimo i da su vjerojatno, čuvajući uspomenu na pobjedu vojvode Vlatka Vukovića nad Turcima, u Bileći imenovanjem ulice njegovo ime oteli zaboravu, ${ }^{80}$ a također i u Trebinju jedna ulica nosi njegovo ime. ${ }^{81}$ Osim toga, vrijedi spomenuti kako je prema jednoj ranijoj odluci Ljubuški jednu ulicu nazvao i po Vlatku, sinu hercega Stjepana Kosače, no ulica s tim nazivom danas ne postoji u Ljubuškome. ${ }^{82}$

Iako su posljednjih godina poduzete neke aktivnosti u cilju očuvanja spomenika vezanih uz hercega Stjepana, čega je najbolji primjer kula hercega Stjepana u Ljubuškome, teško se može razumjeti da još uvijek primjerice na putu Čapljina - Mostar nema nikakve oznake za hercegov grad u Blagaju, niti ima bilo kakav putokaz prema tom

71 http://kosaca-mostar.com/web/onama.php (17. 4. 2016.).

72 http://www.mostar.ba/plan_grada.html (18. 4. 2016.).

73 Službeni glasnik općine Široki Brijeg, 1/2004., str. 30.

74 Službeni glasnik općine Ljubuški, 1/2016., str. 3.

75 Službeni glasnik općine Posušje, 1/2005., str. 8.

76 Narodni list općine Čapljina. Službeno glasilo, 2/2016., str. 50.

77 http://mapeulica.com/mapa-neum-bih-3194514 (18. 4. 2016.).

78 Službeni glasnik općine Tomislavgrad, 3/1991., br. 28.

79 Službeno glasilo Općinskog vijeća općine Čitluk, 8/2013., str. 140-141; Službeno glasilo Općinskog vijeća općine Ćitluk, 5/2015., str. 85-86.

80 http://mapeulica.com/mapa-bileca-bih-3204161 (8. 2. 2016.).

81 Službeni glasnik opštine Trebinje, 4/1994., str. 56.

82 http://www.ljubuski.ba/images/stories/setnja_ljubuskim/prostorni_plan/ mapa_ljubuskog_1280x853.jpg (18. 4. 2016.). Usp. Službeni glasnik općine Ljubuški, 1/2016., str. 3-4. 
spomeniku kulture, čak ni u samom današnjem naselju Blagaj. No, svakako treba reći da postoje neke naznake kako pojedinci i institucije žele ovoj povijesnoj osobi dati značenje koje joj pripada. Naime, u novije vrijeme entuzijasti su pokrenuli inicijativu za obnovu nekih srednjovjekovnih spomenika vezanih uz hercega Stjepana (Stjepangrad u Blagaju i kula herceg Stjepana u Ljubuškome). Također, valja spomenuti i projekt "Tematske rute srednjovjekovne Hercegove zemlje - tema srednji vijek", čija je realizacija u tijeku, a u sklopu ovoga projekta, između ostaloga, planira se rekonstrukcija ceste prema kuli hercega Stjepana u Ljubuškom. ${ }^{83}$ Ostaje nam nadati se da će mjerodavne institucije na kulturu gledati kao na neprocjenjivo blago i da se tim vrijednostima ne će pristupati selektivno, odnosno kako nekoj grupaciji ili interesno-nacionalnoj politici odgovara.

83 http://www.vecernji.ba/na-proljece-obnova-ceste-ka-kuli-hercega-stjepanakosace-1056088 (17. 11. 2016.). 


\section{Reception of the Herzog Stjepan Vukcic Kosaca in Herzegovina in the Second Half of the $20^{\text {th }}$ Century}

\section{Summary}

With the aim of presenting the reception of the Herzog Stjepan Vukcic Kosaca in Hercegovina in the second half of the $20^{\text {th }}$ century, the paper analyzes the contents of history textbooks that write about the life and work of the Herzog Stjepan and his presence in the names of streets, squares and institutions in Herzegovinian towns and municipalities. Considering the second half of the $20^{\text {th }}$ century, most attention is paid to the period in which Bosnia and Herzegovina was one of the republics of the former Yugoslavia. To illustrate the contents from medieval history, or the ones related to Stjepan, most important are school curricula, in which, apart from the teaching units and lessons, the teaching of history was particularly indicative, when during this period the constant task was "spreading fraternity and unity" or "developing patriotic awareness among students", the emphasis being on teaching history of the "newer period". Judging by the curricula and the content of textbooks from the second half of the $20^{\text {th }}$ century (at least those available to us), the youth of Herzegovina in the mentioned period could not learn much about this historical person whose name is associated with the name of the area in which they live. Namely, by looking at the texts of the textbooks up to the $90 \mathrm{~s}$, it is evident that the texts in the textbooks differ, both in scope and emphasis on certain facts. What all the authors mention is taking of the 'Herzog' title in 1448 and the fall of Herzegovina under the Ottoman rule, whereas all the other facts about the Herzog Stjepan vary from one text to another. As there were no official textbooks in the region of Herzegovina in the $90 \mathrm{~s}$ of the $20^{\text {th }}$ century, the paper, as an example, presents the texts only from two textbooks (one for elementary school and the other for grammar school) used in some schools in Herzegovina which worked according to the Croatian curriculum, where we can find hardly any information about the Herzog Stjepan.

Finally, the results of the research of the Herzog's presence in the names of streets, squares and institutions of the Herzegovinian cities and municipalities show that the in- 
terest of some individuals and institutions, who want to give this historical person the significance he deserves, has only recently become evident. Namely, all the streets in Herzegovina named after the Herzog, as well as one institution, got this name after 1990 .

Keywords: Herzog Stjepan Vukcic Kosaca; Herzegovina; reception; history textbooks; streets. 